\title{
ЕКОНОМІКА
}

\begin{tabular}{l}
$\begin{array}{l}\text { Науковий вісник Нлту України } \\
\text { Scientific Bulletin of UNFU } \\
\text { https://nv.nltu.edu.ua }\end{array}$ \\
$\begin{array}{l}\text { https://doi.org/10.36930/40300115 } \\
\text { Article received 23.01.2020 p. } \\
\text { Article accepted 27.02.2020 p. } \\
\text { UDY ISS 1994-7836 (print) } \\
\text { ISSN 2519-2477 (online) }\end{array}$ \\
$\begin{array}{l}\text { UDK 630*[651.2+73] } \\
\text { Correspondence author } \\
\text { I. N. Zhezhkun } \\
\text { desna-90@ukr.net }\end{array}$ \\
\hline
\end{tabular}

I. М. Жежкун

Украӥнський ордена "Знак потани" науково-дослідний інститут лісового господарства і агролісомеліорації ім. Г. М. Висоиького, м. Харків, Україна

\section{ЛІСОРЕСУРСНІ РЕНТНІ ПЛАТЕЖІ В УКРАЇНІ ЗА УМОВ ЗНАЧНОГО КОЛИВАННЯ ЦІН НА ПРОДУКЦІЮ НЕОБРОБЛЕНОЇ ДЕРЕВИНИ}

\begin{abstract}
Розглянуто теоретичні і законодавчі аспекти та практичні наслідки для лісогосподарської галузі та сільських територіальних громад в Україні від вилучення рентних платежів за спеціальне використання лісових ресурсів (деревини). Доведено недосконалість сучасного механізму визначення обсягів рентних платежів за заготівлю деревини за недостатнього економічного обгрунтування рівня їх ставок при періодичному директивному підвищенню та неузгодженості у короткотерміновій перспективі (у межах року) з динамікою цін на продукцію необробленої деревини та витрат постійних лісокористувачів на рубання та відновлення деревного ресурсу. З'ясовано, що особливо значні негативні наслідки для фінансово-економічного стану підприємств лісогосподарської та деревообробної галузей країни через надмірне рентне оподаткування спостерігаються в умовах раптового стрімкого падіння цін на продукцію необробленої деревини (2013 та 2019 рр.). Виявлено наявність в Україні, як і в інших європейських країнах, нерегулярних та циклічних коливань цін на продукцію необробленої деревини. Оцінено вплив на посилення кризового фінансово-економічного стану постійних лісокористувачів багаторесурсної Поліської частини України стрімкого підвищення за останні (2018-2019) роки податкового навантаження (ставок рентних платежів за спеціальне використання лісових ресурсів (на 16,8 та 50,0 \%), введення з середини 2018 р. податку на лісові землі) при істотному скороченні попиту та цін реалізації продукції круглого лісу (за півроку у 2019 р. на 6-59 \%). Визначено, що частка рентних платежів за спеціальне використання лісових ресурсів, починаючи з 2016 р., в 1,2-2,4 раза перевищувала витрати державного бюджету на ведення лісового та мисливського господарства, що зумовлює фіскальний, а не стимулятивний характер оподаткування галузі. Запропоновано вдосконалений механізм нарахування рентних платежів за заготівлю деревини через визначення еквівалентного (справедливого) їх розміру як важливої складової фінансово-економічного механізму лісогосподарювання в умовах децентралізації влади та реформи місцевого самоврядування. Рекомендовані зміни впроваджують ринковий механізм розрахунку рентних платежів за заготівлю деревини, які узгоджують обсяг рентних зобов'язань лісокористувачів з динамікою квартальних аукціонних цін на продукцію необробленої деревини.

Ключові слова: постійні лісокористувачі; спеціальне лісокористування; оподаткування; обсяги заготівлі та реалізації деревини; сільські територіальні громади; бюджетні видатки.
\end{abstract}

Вступ. Використання природних ресурсів (надр, землі, кар'єрів, лісу, води тощо) для виробничих цілей у розвинених країнах світу є платним. Плата за вилучення лісових ресурсів для цілей спеціального лісокористування $є$ формою реалізації економічних відносин між власником лісу (в Україні - народом, від особи котрого виступають органи державної влади та місцевого самоврядування [9]) і лісокористувачами (підприємствами різних форм власності). Ї̈ї визначають на основі ренти, що обчислюється як різниця між ціною лісу на корені у віці рубки та індивідуально зведеними витратами лісокористувача, пов'язаними 3 його відновленням в даних умовах місця зростання [5]. Рентний дохід (земельна рента) у законодавстві України визначають як дохід, котрий можна отримати 3 землі як чиннику виробництва. Усі рентні платежі в Україні віднесено до податкових і зараховуються у встановлених пропорціях до бю-

джетів відповідних рівнів [13]. Однак, незважаючи на чітке теоретичне та законодавче визначення ренти, практичне встановлення та справляння у динаміці іiі економічно обгрунтованого рівня за спеціальне використання лісових ресурсів в Україні залишається досить складним та суперечливим завданням, що зумовлюе потребу в пошуку нових методичних підходів до іï визначення [10].

Об'єкт дослідження - економічна діяльність зі заготівлі деревини та рентні платежі підприємств лісогосподарської галузі України у динаміці за 2007-2019 pp.

Предмет дослідження - взаємозв'язок у динаміці обсягів заготівлі, цін на продукцію необробленої деревини та рентних платежів за використання деревного ресурсу лісу і обгрунтованість наявного економічного механізму нарахування рентних платежів за заготівлю деревини в умовах істотного коливання цін на продук-

\section{Інформація про авторів:}

Жежкун Ірина Миколаївна, канд. екон. наук, ст. наук. співробітник. Email: desna-90@ukr.net

Цитування за ДСтУ: Жежкун І. М. Лісоресурсні рентні платежі в Україні за умов значного коливання цін на продукцію необробленої деревини. Науковий вісник НЛтУ України. 2020, т. 30, № 1. С. 88-93.

Citation APA: Zhezhkun, I. N. (2020). Payments of forests rent in Ukraine in the conditions of significant variation of prices on the products of untreaded lumber. Scientific Bulletin of UNFU, 30(1), 88-93. https://doi.org/10.36930/40300115 
цію круглого лісу.

Мета дослідження - проаналізувати наявний в Україні механізм нарахування, динаміку обсягів справляння рентних платежів за заготівлю деревини та запропонувати вдосконалений методичний підхід щодо визначення "ринкового" (науково обгрунтованого) їх рівня для умов раптового та істотного коливання цін на продукцію необробленої деревини.

Матеріал і методи дослідження. Для вивчення проблематики та пошуку шляхів іiі розв'язання використано загальні наукові методи абстрагування, аналізу та синтезу. Для здійснення якісного аналізу динамічних економічних процесів застосовано кількісні методи економічної статистики, порівняння, табличного і графічного моделювання. Абстрактно-логічний метод теоретичних та фактичних узагальнень використано для формулювання висновків та пропозицій. Інформаційну базу дослідження становили: кодекси України; статистична інформація Державної казначейської служби України та Державного комітету статистики України; Закони України; дані ДП "Лісогосподарський ІнноваційноАналітичний центр" Державного агентства лісових ресурсів Україні та наукові статті за розглянутою темою досліджень.

Результати дослідження та їх обговорення. Значне зростання за останні (2018-2019) роки ставок рентних платежів за спеціальне використання лісових ресурсів деревини (у 2018 р. - на 16,8 \%, у 2019 р. - на $50 \%$ до рівня попереднього року) в умовах світового та внутрішнього падіння попиту та цін на неї істотно негативно позначилось на фінансовому стані лісогосподарської галузі України [14]. Ситуація фінансової дестабілізації лісогосподарської галузі держави стала можливою і завдяки не запровадженого в Україні механізму справляння 3 лісокористувачів ринкового, тобто "справедливого", а не директивне встановленого рівня рентних платежів за спеціальне використання лісових ресурсів. За періодичного (рішеннями, затвердженими Постановами КМУ) підвищення рівня ставок рентних платежів за спеціальне використання лісових ресурсів, особливо деревини, рівень лісоресурсної ренти був або значно нижчим (1996-2017 рр.), або, навпаки, надмірним (2018-2019 pp.) за економічно обгрунтований [15, 21]. У першому випадку надлишковий (не вилучений податком) обсяг ренти умовно поділяється між підприємствами лісогосподарської та деревообробної галузей. У другому - наслідком $є$ кризові фінансові явища у підприємств зазначених галузей за надприбутків держави та місцевих громад, як основних одержувачів рентних платежів.

Щодо стрімкого підвищення вкладу лісової ренти у соціально-економічний розвиток не лише держави, а i сільських територіальних громад свідчать дослідження Ю. Марчука [11]. За його розрахунками, у порівняних цінах у 2017 р. до рівня 1999 р. реальні надходження рентної плати за спеціальне використання лісових ресурсів до сільських бюджетів в Україні збільшилися у 6,9 раза, а їх частка у доходах від ресурсної ренти (разом із користуванням надрами, водою) ще до введення податку на лісові землі [20] становила 74,7\%. Отже, для забезпечення балансу економічних інтересів постійних лісокористувачів та одержувачів рентних платежів за спеціальне використання лісових ресурсів необхідно забезпечити еквівалентне вилучення лісоресур- сної ренти як важливого складника фінансово-економічного механізму лісогосподарювання в умовах децентралізації влади та реформи місцевого самоврядування [11].

Проте зараз в Україні не запроваджений ринковий механізм нарахування ренти за спеціальне використання лісових ресурсів. Лісоресурсна рента за ринкового механізму справляння грунтується на вилученні "справедливого" іiі рівня, зокрема, і в разі істотної в короткотерміновій перспективі (у межах року) динаміки цін на продукцію необробленої деревини. Отже, для вилучення ринково обгрунтованого рівня рентних платежів за заготівлю деревини необхідно передбачити можливість їх корегування залежно від кон'юнктури ринку.

Отже, назріла об'єктивна потреба запровадження змін до наявного підходу в справлянні рентних платежів за заготовлену деревину 3 фіксованого впродовж календарного року їх рівня, який не дає змоги оперативно реагувати на динаміку цін на продукцію круглого лісу, до більш гнучкого та обгрунтованого як для постійних лісокористувачів, так і одержувачів рентних платежів (держави та місцевих громад).

Дослідженнями за період 2005-2018 рр. квартальних обсягів заготівлі та цін реалізації деревини у державних лісах Польщі виявлено нерегулярні, сезонні та циклічні їх коливання [2]. При цьому, якщо нерегулярні (випадкові) коливання у річному часовому горизонті становили лише $6,7 \%$ у загальній мінливості цін та $28 \%$ - в обсягах пропозиції деревини за невеликою їх амплітудою (+ 5 \% та $-25 \%$ ), то циклічні коливання цін та пропозицій деревини траплялись 3 періодичністю у 2-4 роки 3 амплітудою змін у 3-27 євро на $1 \mathrm{~m}^{3}$. Одною 3 причин нерегулярних та тому важко прогнозованих знижень цін на деревину на регіональних ринках Генрі В. Кінукан називає природні катаклізми (знищення деревостанів на великих площах вітровалами або шкідниками лісу) [8]. За його дослідженнями негативна динаміка цін спостерігається відразу після дії стихійного лиха, а їх відновлення до рівня передкризового періоду відбувається лише приблизно через рік.

Описана науковцем ситуація проявляється на європейському та вітчизняному ринках деревини зі середини 2019 р., коли внаслідок масового всихання деревостанів внутрішні ціни в Україні на сортименти необробленої деревини головних порід (сосни звичайної (Pinus sylvestris L.) та дуба звичайного (Quercus robur L.)) також зменшились на 6-59 \% (рис. 1, 2).

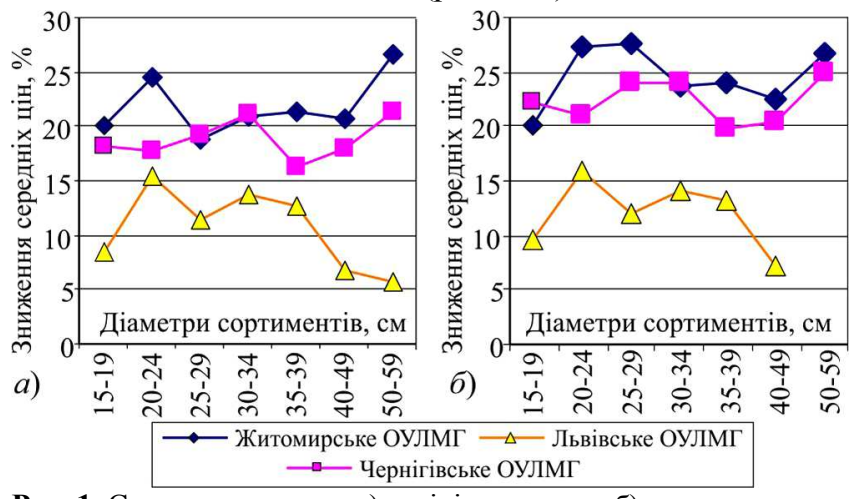

Рис. 1. Середне зниження а) - мінімальних та б) - максимальних продажних аукціонних цін на необроблену деревину (\%) сосни звичайної (клас $\mathrm{C}$, верхній склад) довжиною сортиментів 3-6 м за їх діаметром у III кварталі 2019 р. до рівня у I кварталі 2019 p. [1] 

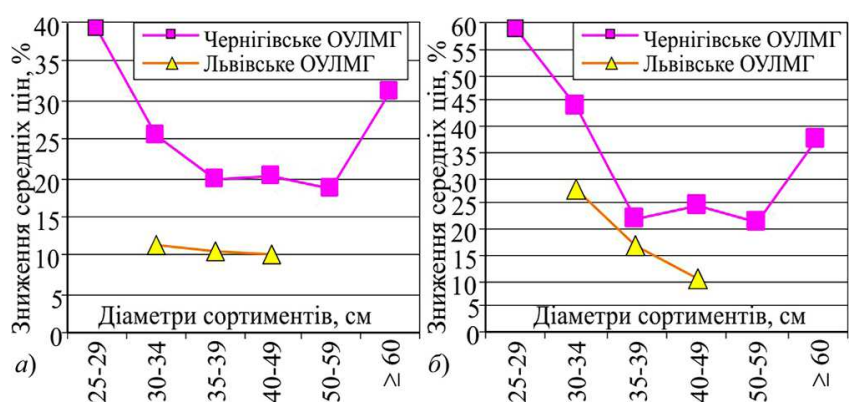

Рис. 2. Середнє зниження а) - мінімальних та б) - максимальних продажних аукціонних цін на необроблену деревину (\%) дуба звичайного (клас $\mathrm{C}$, нижній склад) довжиною сортиментів 1-3 та 2-4 м за їх діаметром у III кварталі 2019 р. до рівня у I кварталі 2019 р. [1]

Згідно 3 нашими розрахунками, за інформацією ДП "Лісогосподарський Інноваційно-Аналітичний центр" [1] зниження цін реалізації сортиментів необробленої деревини сосни та дуба на аукціонах впродовж I півріччя 2019 р. відбувалось у всіх регіонах країни: найбільшою мірою у Північному (Чернігівська обл.) та Центральному (Житомирська обл.), в найменшому - у Малому (Львівська обл.) Поліссі. Так, у першій половині 2019 р. за мінімальними та максимальними аукціонними цінами продаж деякі сортименти необробленої дере- вини сосни звичайної класу С подешевшали в середньому на держаних лісогосподарських підприємствах Житомирського ОУЛМГ від 18,9-26,6 до 20,0-27,5 \%, Чернігівського ОУЛМГ - від 16,2-21,3 до 19,7-25,0 \% та Львівського ОУЛМГ - від 5,6-15,5 до 7,3-16,0 \% (див. рис. 1). За продукцією необробленої деревини дуба звичайного класу $\mathrm{C}$ (аукціон за лотами дуба для підприємств Житомирського ОУЛМГ у першому кварталі 2019 р. не відбувся) зменшення мінімальних і максимальних аукціонних цін реалізації сортиментів у зазначеному періоді в середньому становило за підприємствами Чернігівського ОУЛМГ - від 18,7-39,1 до 21,5$58,7 \%$ та Львівського ОУЛМГ - від 10,2-11,4 до 10,2$27,9 \%$ (див. рис. 2).

В Україні коливання обсягів та цін реалізації деревини також були і в попередньому 10-річному періоді (табл. 1, рис. 3). Так, зниження обсягів заготівлі ліквідної деревини до рівня попереднього року в країні відбулися у 2008-2009 рр. (відповідно на 6,9 та 9,6\%) та у 2017 p. (на 9,7 \%). Скорочення обсягів виторг від реалізації продукції лісозаготівель до рівня попереднього року відбулось у 2009 р. (на 8,6\%) та у 2013 р. (на $21,9 \%)$.

Табл. 1. Динаміка обсягів заготівлі ліквідної деревини круглого лісу та його реалізації [16, 17, 18]

\begin{tabular}{|c|c|c|c|c|c|c|c|c|c|c|c|c|}
\hline Показник & \multicolumn{10}{|c|}{ Значення показників за роками } \\
\cline { 2 - 12 } & 2007 & 2008 & 2009 & 2010 & 2011 & 2012 & 2013 & 2014 & 2015 & 2016 & 2017 & 2018 \\
\hline $\begin{array}{c}\text { Заготівля ліквідної де- } \\
\text { ревини, тис. м }\end{array}$ & 16884 & 15724 & 14221 & 16146 & 17510 & 17507 & 18022 & 18333 & 19268 & 19606 & 18914 & 19696 \\
\hline $\begin{array}{c}\text { Реалізація продукції лі- } \\
\text { созаготівель, млн грн }\end{array}$ & 2576,2 & 2903,9 & 2653,6 & 3530,2 & 5023,4 & 5244,1 & 4095,8 & 7181,9 & 10176,9 & 12274,3 & 12967,7 & $16175,4 *$ \\
\hline
\end{tabular}

Примітка: * - показник у межах України (без урахування експорту).

Найбільш істотне в аналізованому періоді (20072018 рр.) скорочення обсягів реалізації деревини, що відбулось в Україні у 2013 р., супроводжувалось і істотним (на 24,3 \%) падінням середніх цін на продукцію необробленої ліквідної деревини (див. рис. 3).

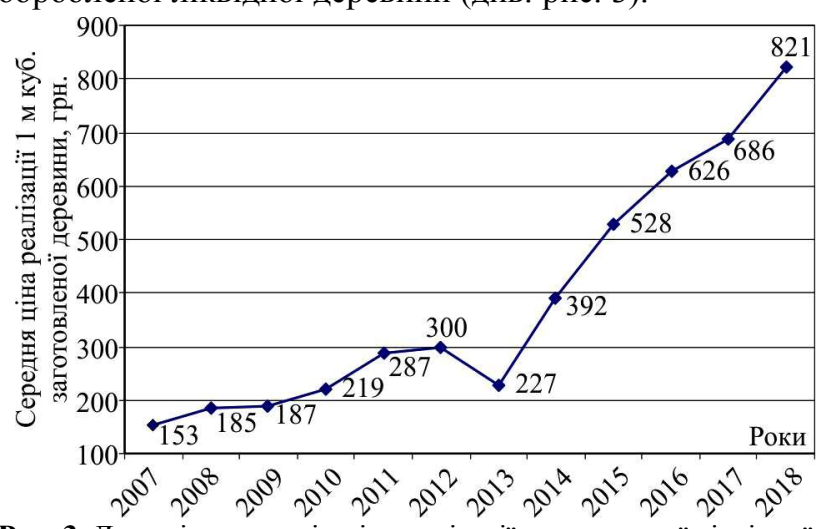

Рис. 3. Динаміка середніх цін реалізації заготовленої ліквідної необробленої деревини, грн/м ${ }^{3}$ (Авторські розрахунки за статистичними даними $[18,17,16])$

В аналізованому періоді (2007-2018 рр.) в Україні за сприятливої кон'юнктури ринку темпи росту середніх цін на продукцію необробленої деревини за роками коливались у широкому діапазоні (від 1,1\% у 2009 р. до 72,7 \% у 2014 р.). Середня ціна продукції круглого лісу у 2018 р. перевищувала таку у 2007 р. у 5,4 раза за збільшення обсягів заготівель деревини за цей період лише на 16,7 \%. Отже, за період 2007-2019 рр. в Україні спостерігались принаймні 2 (у 2013 та у 2019 рр.) періоди істотного (майже на чверть і більше) падіння серед- ніх річних цін на продукцію необробленої деревини. Динаміка останніх за умови втілення в практику господарювання підприємств ринкових механізмів вилучення ренти мала корелювати зі змінами ставок рентних платежів з відтермінуванням цих змін на I квартал (період перерахунку середніх аукціонних цін реалізації деревини). Пряма залежність обсягів нарахованої лісоресурсної ренти від динаміки цін у підсумку забезпечує стабільність частки рентних платежів у структурі собівартості продукції необробленої деревини лісокористувачів. Однак, ставки рентних платежів за спеціальне використання лісових ресурсів в Україні періодично підвищувались, не враховуючи періоди спричиненого кризою зниження цін на деревину (2012-2013 рр. та 20182019 рр.) або стрімкого їх збільшення (2014-2016 рр.) (див. рис. 3). У періоди кризового падіння попиту та цін на продукцію необробленої деревини фінансовими наслідками для лісогосподарських підприємств постають зростання питомої ваги ренти у ціні та обсягах реалізації продукції необробленої деревини та низька рентабельність, або навіть збитковість, здійснення лісозаготівель під час суцільних рубань лісу певних деревних порід (ставки рентних платежів за деревину на не суцільних рубках законодавчо знижені на 50 \%) [13].

Результати аналізу динаміки частки рентних платежів за спеціальне використання лісових ресурсів у максимальних аукціонних продажних цінах у III кварталі 2019 р., порівняно з I, для сортиментів необробленої деревини сосни звичайної класу С та довжиною сортиментів 3-6 м свідчить про іiі збільшення залежно від відстані вивезення деревини (розряду) у різних областях 
України для грубої ділової - від 3,5 до 11,4 \% за першим розрядом рентних платежів та від 1,0 до 3,2 \% за п'ятим розрядом та для середньої ділової - від 5,9 до $15,3 \%$ за першим розрядом та від 0,3 до 0,7 \% за п'ятим (рис. 4).
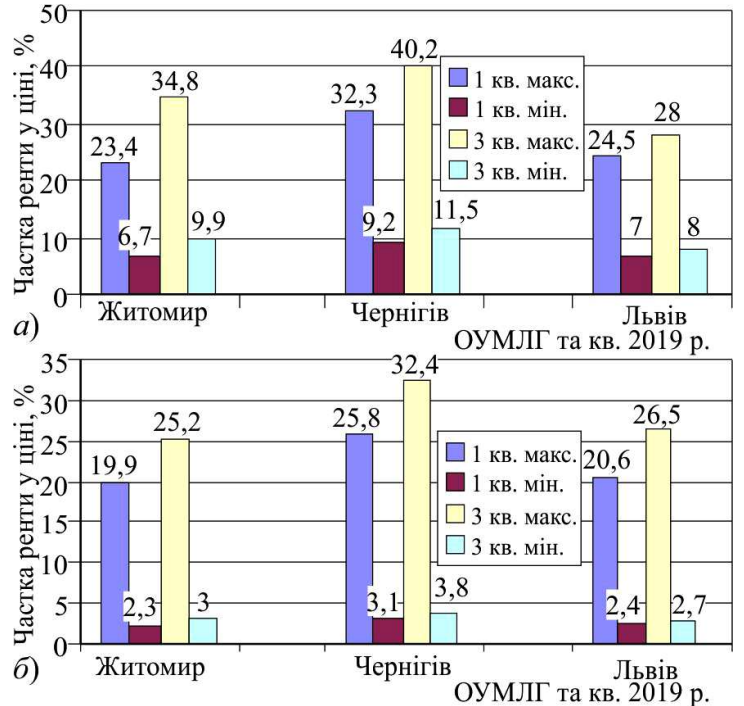

Рис. 4. Динаміка (I та III квартали 2019 р.) частки рентних платежів за максимальними та мінімальними розрядами у максимальних аукціонних цінах продаж (\%) сортиментів необробленої а) - грубої (діаметром, 26 см і більше) та б) - середньої (діаметром 14-24 см) деревини сосни звичайної [7] класу С та довжиною 3-6 м для підприємств Житомирського, Чернігівського та Львівського ОУЛМГ

Водночас, збільшення частки рентних платежів у максимальних аукціонних продажних цінах у III кварталі 2019 р., порівняно з I, за продукцією необробленої деревини дуба, довжиною 1-3 та 2-4 м становило для грубої ділової від 4,3\% за першим розрядом такс до $1,2 \%$ за п'ятим у підприємств Львівського ОУЛМГ та для середньої ділової - від 13,1\% за першим до 3,7 \% за п'ятим розрядом у підприємств Чернігівського ОУЛМГ (рис. 5).

Отже, підвищення податкового навантаження на підприємства лісогосподарської галузі у вигляді ренти відбувається у порівняно більшому розмірі за зростання частки падіння цін реалізації необробленої деревини та зменшення відстані вивезення деревини (розряду такс). Тому максимальне збільшення питомої ваги ренти у цінах реалізації продукції грубої та середньої необробленої деревин сосни та дуба у III кварталі 2019 р., порівняно 3 I, маємо у Житомирському ОУЛМГ, мінімальне - у Львівському.

Посилює нестабільність у фінансовому становищі підприємств - постійних лісокористувачів у державі і ситуація, що склалася у галузі, починаючи з 2019 р., коли за введенням європейських стандартів при реалізації покупцям деревини круглими лісоматеріалами [12] відбувається практика нарахування рентних платежів за заготівлю деревини за старими нормативами, що базуються на різних розмірно-якісних градаціях оцінки продукції $[6,7]$. Відповідно наслідком є нерівнозначність обсягів необробленої деревини при її відпуску покупцям та як бази оподаткування при нарахуванні рентних платежів.
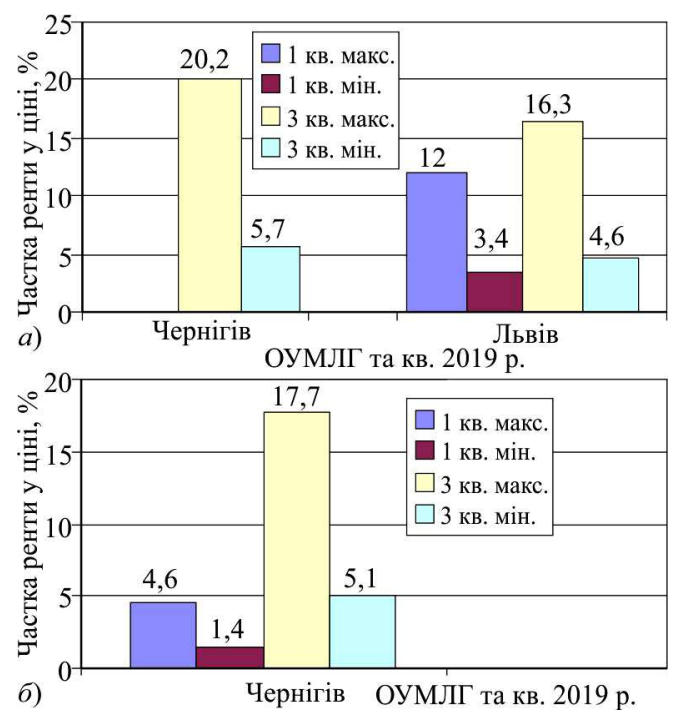

Рис. 5. Динаміка (I та III квартали 2019 р.) частки рентних платежів за максимальними та мінімальними розрядами у максимальних аукціонних цінах продаж (\%) сортиментів необробленої а) - грубої (діаметром, 26 см і більше) та б) - середньої (діаметром 14-24 см) деревини дуба звичайного [6] класу С довжиною 1-3 м та 2-4 м для підприємств Чернігівського та Львівського ОУЛМГ

Відповідно до підвищення обсягів рубок деревини та ставок рентних платежів за спеціальне використання лісових ресурсів переважно зростали в аналізованому періоді (2007-2019) в Україні за роками і обсяги рентних надходжень від лісозаготівель до бюджетів (табл. 2). Водночас, якщо впродовж 2007-2015 рр. обсяги рентних платежів за спеціальне використання лісових ресурсів покривали суми видатків бюджету на ведення лісового та мисливського господарства лише частково (на 16,5-59,3\%), то з 2016 р. почали перевищувати їх в 1,21-2,41 раза (див. табл. 2). Це відбулось завдяки стрімкому підвищенню за останні (2018-2019) роки ставок рентних платежів на деревину за одночасного бюджетного недофінансування підприємств південних та південно-східних малоресурсних областей галузі.

Табл. 2. Динаміка рентних платежів за спеціальне використання лісових ресурсів та видатків бюджету на лісове і мисливське господарство в Україні, млн грн [36, 37]

\begin{tabular}{|c|c|c|c|c|c|c|c|c|c|c|c|c|c|}
\hline Показник & \multicolumn{9}{|c|}{ Значення показників за роками } \\
\cline { 2 - 24 } & 2007 & 2008 & 2009 & 2010 & 2011 & 2012 & 2013 & 2014 & 2015 & 2016 & 2017 & 2018 & $\begin{array}{c}9 \text { міс. } \\
2019\end{array}$ \\
\hline $\begin{array}{c}\text { Рентна плата за спец. } \\
\text { використання лісових } \\
\text { ресурсів }\end{array}$ & 132,4 & 170,5 & 174,6 & 170,0 & 93,1 & 213,6 & 241,5 & 206,5 & 274,9 & 331,4 & 329,7 & 387,0 & 438,4 \\
\hline $\begin{array}{c}\text { Видатки бюджету на лі- } \\
\text { сове та мисливське г-во }\end{array}$ & 366,8 & 567,6 & 378,0 & 454,2 & 565,8 & 640,0 & 637,3 & 485,1 & 463,8 & 137,3 & 211,8 & 296,6 & 362,2 \\
\hline $\begin{array}{c}\text { Частка ренти у видатках } \\
\text { бюджету на лісове та } \\
\text { мисливське г-во, \% }\end{array}$ & 36,1 & 30,0 & 46,2 & 37,4 & 16,5 & 33,4 & 37,9 & 42,6 & 59,3 & 241,4 & 155,7 & 130,5 & 121,0 \\
\hline
\end{tabular}


Вирішення проблеми справляння з лісокористувачів "справедливого" або еквівалентного кон'юнктурі ринку обсягу рентних платежів за заготівлю деревини в умовах нестабільності цін на неї полягає у змінах механізму їх розрахунку. За нашими міркуваннями, ставки рентних платежів мають встановлюватись не на рік, а на квартал за підсумками аналізу аукціонних цін реалізації продукції необробленої деревини за попередній трьохмісячний період. У разі стабільності останніх (коливання у межах до 10 \%) рентні ставки на продукцію необробленої деревини пролонгують на наступний квартал, а за різкої зміни (зниження або підвищення більше ніж на $10 \%$ ) ставки потрібно переглядати у відповідний бік за обгрунтованою динамікою рівня цін. Тільки у цьому випадку, тобто в разі забезпечення оподаткуванням прямої кореляції між динамікою продажних цін на деревину і витрат лісокористувачів на здійснення лісозаготівель та обсягами сплаченої ренти можна констатувати іiі ринковий (економічно обгрунтований) рівень. Для практичної реалізації квартального розрахунку ставок рентних платежів за спеціальне використання лісових ресурсів потрібні законодавчі правки до Податкового кодексу і додаткова робота податківців та фахівців органів статистики зі збирання, аналізу динаміки цін на деревину з біржових квартальних торгів (аукціонів) та своєчасне надання зацікавленим сторонам відповідної оперативної інформації для розрахунків обсягів рентних платежів.

Висновки та пропозиції. Проведений для України аналіз теоретичних, законодавчих підходів щодо справляння рентних платежів за спеціальне використання ресурсів деревини, а також сум рентних надходжень до бюджетів та фактичних даних щодо обсягів заготівлі і реалізації деревини (2007-2019 рр.) дав змогу виявити основні проблеми у сучасній практиці нарахування лісокористувачам економічно обгрунтованого їх рівня та подальшого використання:

1) наявність в Україні, як і в інших європейських країнах, нерегулярних та циклічних коливань цін на продукцію необробленої деревини;

2) фактична відсутність кореляції та механізму узгодження при лісоресурсному рентному оподаткуванні між динамікою цін на продукцію необробленої деревини (особливо в умовах істотного стрімкого у межах року ïx зменшення або підвищення) та ставками рентних платежів за спеціальне використання лісових ресурсів;

3) починаючи з 2019 р., паралельне існування двох різних підходів для оцінювання обсягів продукції необробленої деревини. Для цілей нарахування рентних платежів використовують старі стандарти [7, 6] з поділом за породами обсягів ліквіду на дров'яну та ділову деревину, останньої - за розміром (на грубу, середню та дрібну) та відстанню вивезення (1-5 розрядами). Під час відпуску деревини покупцям оцінку проводять за європейськими стандартами, наприклад, $[3,4]$ з поділом продукції круглого лісу за крупністю та класами якості (А, В, C i D);

4) фіскальна спрямованість за останні (2016-2019) роки практики справляння 3 постійних лісокористувачів рентних платежів за невиправданого недофінансування галузі через обсяги видатків бюджету на ведення лісового та мисливського господарства.

Для вирішення проблеми забезпечення справляння в Україні з постійних лісокористувачів економічно обгрунтованого рівня рентних платежів за спеціальне ви- користання лісових ресурсів доцільно запровадити зміни в механізмі їх нарахування, передбачивши щоквартальний розрахунок ставок залежно від динаміки аукціонних цін реалізації необробленої деревини та витрат лісокористувачів на іiї заготівлю та здійснення наступного лісовідновлення зрубів.

\section{References}

1. Aukcionni ciny. Derzhavne agentstvo lisovyx resursiv Ukrayiny. Oficijnyj veb-sajt DP "Lisogospodarskyj Innovacijno-Analitychnyj centr". Retrieved from: https://www.ukrforest.com/austat. (Date of appeal: 11.12.2019). [In Ukrainian].

2. Banaś, J., \& Kożuch, A. (2019). The Application of Time Series Decomposition for the Identification and Analysis of Fluctuations in Timber Supply and Price: A Case Study from Poland. Forests, 10(11), 990. https://doi.org/10.3390/f10110990

3. DSTU EN 1316-1:2005. (2007). Lisomaterialy krughli lystjani. Klasyfikacija za jakistju. (Part 1: Dub i buk) (EN 1316-1:1997, IDT), from 02 September 2005. Kyiv: Derzhspozhyvstandart Ukrajiny, 6 p. [In Ukrainian].

4. DSTU ENV 1927-2:2005. (2007). Lisomaterialy krughli khvojni. Klasyfikacija za jakistju. (Part 2: Sosna) (ENV 1927-2:1998, IDT), from 02 September 2005. Kyiv: Derzhspozhyvstandart Ukrajiny, 4 p. [In Ukrainian].

5. Dzyubenko, O. M. (2017). Fiscal tools for collection of forest resource rent in the system of investment and innovative support for the reforestation of forest ecosystems. Agrosvit, 23, 8-17. Retrieved from: https://www.agrosvit.info/pdf/23_2017.pdf (Date of appeal: 17.11.2019). [In Ukrainian].

6. GOST 9462-88. (1991). Lesomaterialy kruglye listvenny porod. Tehnicheskie usloviya. Moscow: Izdatelstvo standartov, 14 p. [In Russian]

7. GOST 9463-88. (1991). Lesomaterialy kruglye hvojnyh porod. Tehnicheskie usloviya. Moscow: Izdatelstvo standartov, 14 p. [In Russian].

8. Henry, W. Kinnucan. (2016). Timber price dynamics after a natural disaster: Hurricane Hugo revisited. Journal of Forest Economics, 25(1), 115-129. https://doi.org/10.1016/j.jfe.2016.09.002

9. Lisovyy kodeks (2006). Lisovyy kodeks Ukrayiny vid 20.10.2019 r. Postanova Verkhovnoyi Rady Ukrayiny vid 21.01.1994 r., № 3853-KhII. Retrieved from: https://zakon.rada.gov.ua/ laws/show/3852-12. (Date of appeal: 17.12.2019). [In Ukrainian].

10. Lysychko, A. M. (2018). Development of economic analysis method of rent relations in forestry. (Ser. Economics). The Journal of Zhytomyr State Technological University, 1(83), 15-18. https://doi.org/10.26642/jen-2018-1(83)-15-18

11. Marchuk, Yu. (2018). Equivalent withdrawal of forest resource as an important component of the financial and economic mechanism of Forestry in the context of decentralization. Agrosvit, 22, 47-54. https://doi.org/10.32702/2306-6792.2018.22.47

12. Nakaz DARLU (2018). Pro zakhody $z$ vprovadzhennja nacionaljnykh, gharmonizovanykh $\mathrm{z}$ jevropejsjkymy, standartiv vid 30.10.2018 r., № 910. [In Ukrainian].

13. Podatkovyi kodeks (2011). Podatkovyi kodeks Ukrainy vid 22.05.2019 r. Postanova Verkhovnoyi Rady Ukrayiny, № 2628VIII. Retrieved from: https://zakon.rada.gov.ua/laws/show/275517. (Date of appeal: 17.12.2019). [In Ukrainian].

14. Selinnyi, M., \& Korma, O. (2019). Forestry of Ukraine: Current State and Trospects for Development. Modern Economics, 1(17), 211-217. https://doi.org/10.31521/modecon.v17(2019)-34

15. Sherstyukova, K. Yu. (2017). Redistribution of natural resource rent in the national economy: dysertaciya. [Qualification scientific work on the rights of manuscripts]. Krivoy Rog, Kyiv, 322 p. Retrieved from: https://ipk.edu.ua/science/special_vr/Disertacia Sherstukova.pdf. (Date of appeal: 25.11.2019). [In Ükrainian].

16. Statystychnyy shchorichnyk Ukrayiny za 2012 rik. (2013). Derzhavna sluzhba statystyky Ukrayiny. Kyiv, 552 p. Retrieved from: https://www.ukrstat.gov.ua/druk/publicat/Arhiv_u/01/Arch _zor_zb.htm (Date of appeal: 10.12.2019). [In Ukrainian]. 
17. Statystychnyy shchorichnyk Ukrayiny za 2017 rik. (2018). Derzhavna sluzhba statystyky Ukrayiny. Kyiv, 541 p. Retrieved from: https:/www.ukrstat.gov.ua/druk/publicat/kat_u/2018/zb/11/ zb_seu2017_u.pdf (Date of appeal: 10.12.2019). [In Ukrainian].

18. Statystychnyy shchorichnyk Ukrayiny za 2018 rik. (2019). Derzhavna sluzhba statystyky Ukrayiny. Zhytomyr: TOV "BukDruk", 482 p. Retrieved from: https://www.ukrstat.gov.ua/druk/ publicat/kat_u/2019/zb/11/zb_yearbook_2018.pdf (Date of appeal: 10.12.2019). [In Ukrainian].

19. Stavky rentnoyi platy za spetsialne vykorystannya lisovykh resursiv stanom na 01.01.2019 r. Podatkoviy kodeks Ukrayiny, P. 256.3. Retrieved from: https://services.dtkt.ua/catalogues/tax rates/40 (Date of appeal: 19.12.2019). [In Ukrainian].

20. Zakon Ukrainy (2018). Pro vnesennia zmin do Podatkovoho kodeksu Ukrainy ta deiakykh zakoniv Ukrainy shchodo stymuliuvannia utvorennia ta diialnosti simeinykh fermerskykh hospodarstv vid 10.07.2018 r. № 2497-VIII. Retrieved from: https://search.ligazakon.ua/1_doc2.nsf/link1/T182497.html. [In Ukrainian].

21. Zhezhkun, I. M. (2019). Dual taxation of forest lands in Ukraine and its consequences for forestry and woodworking indastry. Scientific Bulletin of UNFU, 29(8), 97-101. https://doi.org/10.36930/40290817

22. Zvity pro vykonannya Derzhavnoho byudzhetu Ukrayiny. (2007). Retrieved from: https://www.treasury.gov.ua/ua/file-storage/richniy-zvit-6

23. Zvity pro vykonannya Derzhavnoho byudzhetu Ukrayiny. (2008). Retrieved from: https://www.treasury.gov.ua/ua/file-storage/richna-zvitnist-11

24. Zvity pro vykonannya Derzhavnoho byudzhetu Ukrayiny. (2008). Retrieved from: https://www.treasury.gov.ua/ua/file-storage/richniy-zvit-5

25. Zvity pro vykonannya Derzhavnoho byudzhetu Ukrayiny. (2009). Retrieved from: https://www.treasury.gov.ua/ua/file-storage/richniy-zvit-4

26. Zvity pro vykonannya Derzhavnoho byudzhetu Ukrayiny. (2010). Retrieved from: https://www.treasury.gov.ua/ua/file-storage/richniy-zvit-3
27. Zvity pro vykonannya Derzhavnoho byudzhetu Ukrayiny. (2011). Retrieved from: https://www.treasury.gov.ua/ua/file-storage/richniy -zvit-2

28. Zvity pro vykonannya Derzhavnoho byudzhetu Ukrayiny. (2012). Retrieved from: https://www.treasury.gov.ua/ua/file-storage/richniy -zvit

29. Zvity pro vykonannya Derzhavnoho byudzhetu Ukrayiny. (2013). Retrieved from: https://www.treasury.gov.ua/ua/file-storage/richniy -zvit-stanom-na-01012014

30. Zvity pro vykonannya Derzhavnoho byudzhetu Ukrayiny. (2014). Retrieved from: https://www.treasury.gov.ua/ua/file-storage/richniy -zvit-pro-vikonannya-derzhavnogo-byudzhetu-na-01012015-roku

31. Zvity pro vykonannya Derzhavnoho byudzhetu Ukrayiny. (2015). Retrieved from: https://www.treasury.gov.ua/ua/file-storage/richniy -zvit-pro-vikonannya-derzhavnogo-byudzhetu-ukraini-za-2015-rik

32. Zvity pro vykonannya Derzhavnoho byudzhetu Ukrayiny. (2016). Retrieved from: https://www.treasury.gov.ua/ua/file-storage/richniy -zvit-pro-vikonannya-derzhavnogo-byudzhetu-ukraini-za-2016-rik

33. Zvity pro vykonannya Derzhavnoho byudzhetu Ukrayiny. (2017). Retrieved from: https://www.treasury.gov.ua/ua/file-storage/richniy -zvit-pro-vikonannya-derzhavnogo-byudzhetu-ukraini-za-2017-rik

34. Zvity pro vykonannya Derzhavnoho byudzhetu Ukrayiny. (2018). Retrieved from: https://www.treasury.gov.ua/ua/file-storage/richnij -zvit-pro-vikonannya-derzhavnogo-byudzhetu-ukrayini-za-2018-rik

35. Zvity pro vykonannya Derzhavnoho byudzhetu Ukrayiny. (2019). 9 mis 2019 roku. Retrieved from: https://www.treasury.gov.ua/ ua/file-storage/kvartalnij-zvit-pro-vikonannya-derzhavnogobyudzhetu-ukrayini-za-devyat-misyaciv-2019-roku (Date of appeal: 12.12.2019). [In Ukrainian].

36. Zvity pro vykonannya Derzhavnoho byudzhetu Ukrayiny. (2019). Richnyy zvit. Vydatky za funktsionalnoyu klasyfikatsiyeyu vydatkiv ta kredytuvannya byudzhetu. Retrieved from: https://www.treasury.gov.ua/ua/file-storage/richniy-zvit

37. Zvity pro vykonannya Derzhavnoho byudzhetu Ukrayiny. (2019). Richnyy zvit. Dokhody. Retrieved from: https://www.treasury.gov.ua/ua/file-storage/richniy-zvit

I. N. Zhezhkun

Ukrainian Research Institute of Forestry and Forest Melioration named after G. M. Vysotsky, Kharkiv, Ukraine, Ukraine

\section{PAYMENTS OF FORESTS RENT IN UKRAINE IN THE CONDITIONS OF SIGNIFICANT VARIATI- ON OF PRICES ON THE PRODUCTS OF UNTREADED LUMBER}

With a clear theoretical and legislative definition of forest resource rent, the practical establishment and management of the dynamics of its economically justified level in Ukraine remains a difficult and contradictory task, especially for conditions of sharp fluctuations in the market conditions and prices for the production of untreated lumber, which necessitates the need for new methods of searching approaches to its definition. The research used common scientific methods of abstraction, analysis and synthesis. Quantitative methods of economic statistics, comparisons, tabular and graphical modeling, and abstract-logical methods of theoretical generalizations are also applied. The article analyzes the dynamics of volumes of harvesting and sale of timber, as well as the rent paid by permanent forest managers during the period of 2007-2019 in Ukraine. The existence of irregular and cyclical fluctuations in the prices of untreaded lumber production is proved in the considered period and their negative impact on the financial and economic state of the forestry industry of the country is determined. The destabilizing impact on the financial condition of the enterprises of the forestry sector by irregular (sudden), i.e. caused by difficultly predicted factors (natural disasters, mass drying of forests due to damage by pests and diseases, etc.) fluctuations (fall) of prices for products of untreated lumber is identified in 2013 and 2019. Significant decrease (by 6-59\%) of prices for assortment of round wood of enterprises of Polissya part of Ukraine (in particular, Chernihiv, Zhytomyr and Lviv RFHM) in the first half of 2019 while disproportionate increase of the tax burden at on the industries (additional introduction of the tax on forest lands in 2018 and increase in rent rates for timber harvesting by $16.8 \%$ and $50.0 \%$ respectively in 2018-2019) led to the increase in the share of rents in the structure of costs of permanent forest managers and caused the loss of clear felling of certain tree species (first of all, pine). Moreover, starting from 2016, the fiscal orientation of rent payments from forestry enterprises in Ukraine is confirmed by an excess of 1.2-2.4 times of their volume compared to the state budget expenditures on forestry and hunting. As a result, in order to ensure the balance of economic interests of the payers of forest resource rent and its recipients (rural territorial communities and the state), it is necessary to set the task of equivalent dynamics of prices and costs for harvesting wood and restoration of the forests, which will be scientifically substantiated, based on the theory and at the same time by fair (market) for forest managers. To solve the problem of reconciling the volume of accrued forest resource rent with the dynamics of the timber market, quarterly recalculation and adjustment (in case of more than $10 \%$ of the dynamics of average auction prices) of the level of rent payments for special forest exploitation is offered. There is also a need for methodological and legislative reconciliation of the problem of different approaches (from 2019) to the sale to buyers (by modern European standards) and to the accrual (by the domestic, dating from the $1980 \mathrm{~s}$ ) to permanent forest managers of rent payments for products of untreaded lumber.

Keywords: permanent forest managers; special forest exploitation; taxation; volumes of lumber harvesting and sales; rural territorial communities; budget expenditures. 